\title{
HUMANISTYKA CYFROWA
}

Cristina Dondi

Oksford

\section{Piętnastowieczny handel książką* Gromadzenie świadectw źródłowych i badanie inkunabułów - baza danych MEI}

Przyjrzyjmy się poniższym pytaniom: Które spośród książek wydrukowanych w Wenecji eksportowano, nabywano i użytkowano w Niemczech lub w Polsce w XV wieku? Które - z wydrukowanych w Norymberdze trafiły do Włoch w wieku XVI? Jakie to były książki i kto je używał? Do jakich celów? Ile kosztowały wczesne druki? Czy czytywały je kobiety? Jakie książki kupowali studenci a jakie prawnicy lub duchowni w XV, XVI wieku, albo w późniejszych stuleciach we Włoszech, Francji, lub gdziekolwiek indziej? Które spośród wydań dzieł matematycznych zakupywały instytucje religijne? Kto kupował Ptolemeusza w czasach renesansu? Kto kolekcjonował edycje jego dzieł w wieku XVIII? Czy jesteśmy w stanie ująć kwantytatywnie druki piętnastowieczne, które weszły w skład kolekcji europejskich i amerykańskich bezpośrednio na skutek likwidacji instytucji religijnych i ich księgozbiorów w wiekach XVIII i XIX?

Ile razy ukazał się w druku Petrarka albo Boccaccio w wieku XV? Jaki procent wszystkich druków z okresu pierwszych pięćdziesięciu lat od wynalazku Gutenberga to dzieła literatury klasycznej, jaki - średniowiecznej, a jaki to prace autorów współczesnych? Które tytuły dotrwały do dnia dzisiejszego w największej liczbie? A które w najmniejszej?

Kto dobierał prace do druku, kto redagował i kto łożył na produkcję piętnastowiecznych wydań? Czy możemy zrekonstruować proces edycji

* W grudniu 2013 r. Cristina Dondi otrzymała European Research Council Consolidator Grant na projekt badawczy „Piętnastowieczny handel książką: oparta na źródłach ocena i wizualizacja dystrybucji, sprzedaży i recepcji książki w dobie renesansu”. 
korpusu tekstów, które dotarły do nas dzięki temu nowemu medium? Ile właściwie wydrukowano tytułów w XV w. (czy też ile dotrwało do dnia dzisiejszego) w pojedynczych lub wielokrotnych wydaniach? Ile edycji zostało opatrzonych ilustracjami? Czy rozporządzamy wyznacznikami poziomu, które pozwolą nam określić jakość i liczebność tego, co utraciliśmy w ciagu pięciuset lat od wynalezienia ruchomej czcionki?

Wszystkie powyższe pytania mają dwie cechy wspólne: po pierwsze odnoszą się bezpośrednio do naszej wiedzy na temat wpływu wynalazku druku na społeczeństwo wczesnonowożytnej Europy; po drugie zaś: nie jesteśmy zdolni odpowiedzieć na żadne z nich!

Po dziś dzień zachowało się około 30 tys. wydań inkunabułów, przeciętnie po piętnaście egzemplarzy każdego ${ }^{1}$. W sumie daje to 450000 książek, znajdujących się w przybliżeniu w czterech tysiącach różnych bibliotek publicznych, głównie w Europie i Ameryce Północnej. Każde z wydań zostało uwzględnione w Incunabula Short-Title Catalogue (ISTC) prowadzonym przez British Library, który także odnotowuje obecne miejsce przechowywania większości zachowanych kopii. Typograficzny opis tychże wydań jest dostępny w Gesamtkatalog der Wiegendrucke (GW), stworzonym w Staatsbibliothek w Berlinie.

Każdy egzemplarz książki, która dotrwała do naszych czasów, ma własną historię, którą można rekonstruować w oparciu o dane fizyczne (notki własnościowe, dekoracja, oprawa, herby, marginalia, pieczatki, wyceny księgarskie itp) oraz dane bibliograficzne (katalogi dawnych księgozbiorów, katalogi aukcyjne, księgi nabytków itd), co wspólnie określa się jako świadectwa właściwe danemu egzemplarzowi, proweniencję, lub dane źródłowe powstałe po wytworzeniu kopii.

Każdy dział zbiorów specjalnych należący do europejskiej lub amerykańskiej biblioteki naukowej składa się ze swoistych membra disiecta, tzn. części różnych kolekcji rozproszonych, nierzadko wielokrotnie, w którymś momencie dziejów. Powody dzielenia zbiorów były różne: dziedziczenie, sprzedaż, darowizna, zamiana, kradzież, grabież wojenna, sekwestracja, modernizacja, zaniedbanie, albo polityka państwowa względem dziedzictwa narodowego, a zwłaszcza jej specyficzny przejaw, polegajaccy na zamykaniu instytucji religijnych, co, między XVI a XX w., zaszło w większości krajów europejskich².

${ }^{1}$ Wydania wenckie zachowały się $\mathrm{w}$ większej liczbie egzemplarzy, przeciętnie po ok. 40 kopii na wydanie. 10\% tego zasobu autorka niniejszego artykułu i Paul Needham przeliczyli własnoręcznie.

${ }^{2}$ Indeks proweniencji katalogu inkunabułów Biblioteki Bodlejańskiej w Oksfordzie (Bod-inc) wylicza przeszło cztery tysiące (4054) byłych posiadaczy, tak indywidualnych jak instytucjonalnych. W przypadku harwardzkiej Houghton Library, katalog autorstwa Jamesa Walsha wykazuje 2650 proweniencji. Podobną różnorodność znajdujemy w przypadku British Library, Bibliothèque nationale de France, Rosyjskiej Biblioteki 
Od stu lat, a od pięćdziesięciu z coraz bardziej wzrastającą częstotliwościa, publikowane są drukowane katalogi inkunabułów, z różną precyzją opisujące ich postać fizyczną i proweniencję. W sumie ukazało się już kilka setek tych wydawnictw. Jednak w ostatnich latach gromadzenie danych dotyczących inkunabułów coraz częściej prowadzone jest w ramach katalogów komputerowych poszczególnych bibliotek ${ }^{3}$. W obliczu pragmatyki zarządzania zbiorami, tego rodzaju rozstrzygnięcia są zrozumiałe, niemniej prowadzą one do fragmentacji zasobów informacyjnych, co w konsekwencji czyni wykorzystanie tych cennych danych do badań historycznych praktycznie niemożliwe. W jaki sposób historyk zajmujący się biblioteką Angelo Poliziano (zm. 1494), czy też kartuzją bazylejską ma odgadnąć, że książki należące do uczonego lub instytucji, którą bada, dziś przechowywane są w Oksfordzie, Paryżu, Liverpoolu, lub gdziekolwiek indziej? W jaki sposób badacze mieliby przekopywać się przez setki (a już w niedalekiej przyszłości przez tysiące) elektronicznych katalogów bibliotecznych, by odszukać informacje, które są im potrzebne?

Dane proweniencyjne, tak jak książki, których dotycza, nadal pozostają disiecta membra. Nadal rozrzucone są po setkach publikacji papierowych i setkach, a już wkrótce tysiącach, elektronicznych katalogów bibliotecznych. Ponieważ kolekcje są rozproszone, tak też rozproszone są ich opisy. Jeżeli więc chcemy uzyskać obraz całości, by poddać go procedurom badawczym, musimy dokonać zintegrowania danych katalogowych.

\section{Integrowanie rekordów dla celów badawczych}

Baza danych Material Evidence in Incunabula (MEI) została stworzona właśnie po to, by pokonać tę poważną przeszkodę w posługiwaniu się inkunabułami jako źródłami do badań historycznych: w MEI integrujemy istniejące już rekordy, rozproszone dotychczas po katalogach kartkowych i elektronicznych, dodając do nich opisy indywidualnych cech tysięcy konkretnych egzemplarzy, przechowywanych w większych i mniejszych księgozbiorach, które dotychczas nie zostały skatalogowane. Co jeszcze ważniejsze, stworzyliśmy nowy sposób strukturalizowania danych proweniencyjnych, który wreszcie pozwoli na odpowiedzenie na ważkie pytania związane $\mathrm{z}$ handlem i użytkowaniem książki w XV w.

\footnotetext{
Narodowej w Petersburgu, czy Morgan Library w Nowym Jorku. W różnej skali występuje ona praktycznie w każdej bibliotece świata zachodniego.

${ }^{3}$ Lucien Febvre i Henri-Jean Martin (L'apparition du livre, Paris 1958; przekład ang. The Coming of the Book, London 1976) nie tylko otworzyli drogę do nowych gałęzi wiedzy o książce w Europie, lecz także, kładąc nacisk na badania źródłowe i cechy fizyczne książek, na następne pięćdziesiąt lat zainspirowali i zmotywowali do katalogowania materialnych świadectw dawnej książki drukowanej w indywidualnych bibliotekach.
} 


\section{Śledzenie ruchu książek}

Zbiory biblioteczne postrzegamy na ogół jako twory statyczne, tymczasem książki w ich skład wchodzące, a zwłaszcza te, które pochodza z kolekcji historycznych, w trakcie swej długiej, nierzadko wielowiekowej, historii przemierzały świat wzdłuż i wszerz.

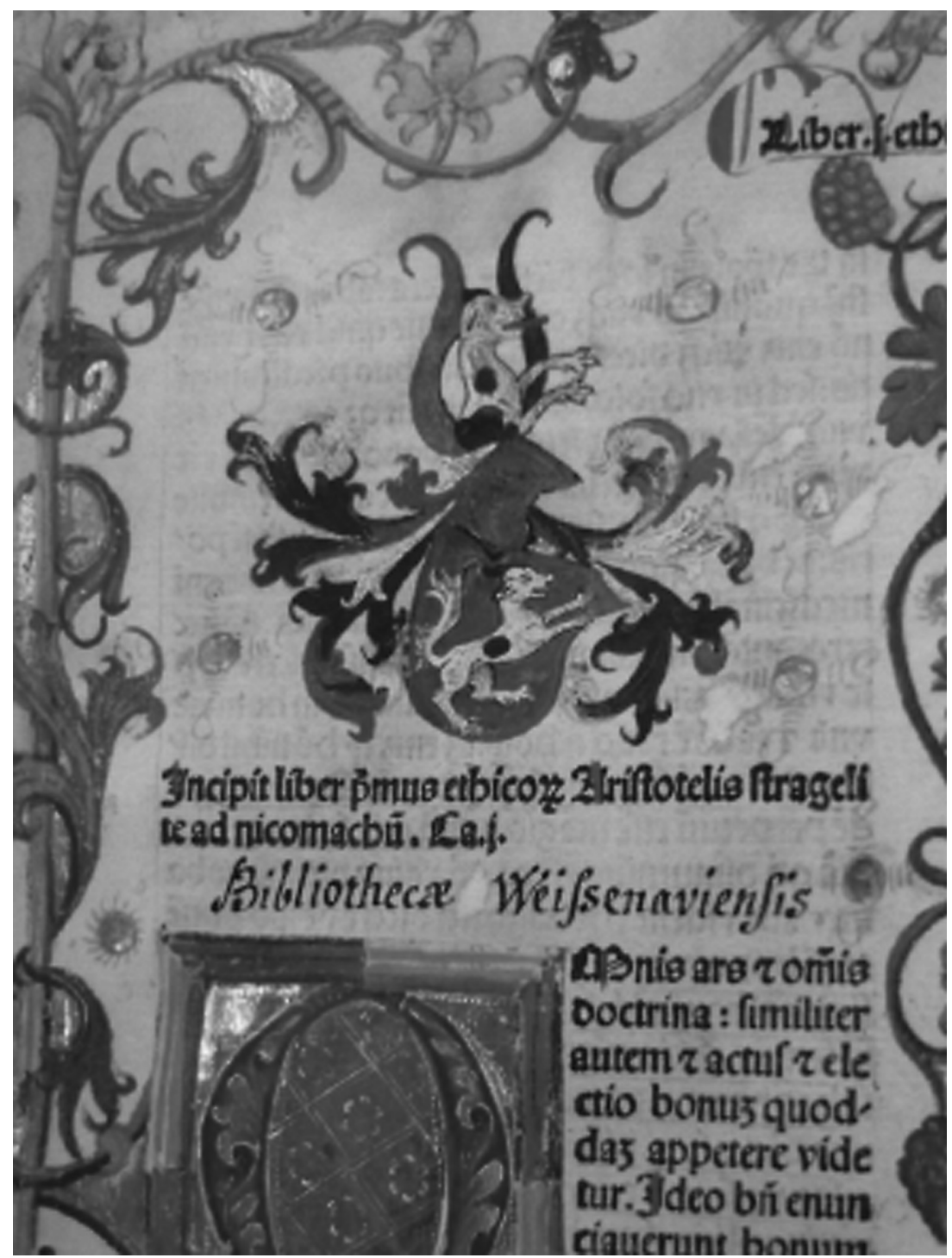

Il. 1. Aristoteles, Opera, Venetia: A. Torresanus i B. de Blavis, 1483; folio; ISTC ia00962000; Bod-inc A-387(1); własność: Oxford, Bodleian Library, sygn. Auct. P inf. 1.3, k. A1r. 
W Bibliotece Bodlejańskiej znajduje się egzemplarz edycji Arystotelesa wydrukowanej $\mathrm{w}$ Wenecji. Książka ta przewieziona została do południowych Niemiec, gdzie dodane zostały iluminacje, i gdzie służyła zgromadzeniu premonstratensów w Weissenau. Druk ten przebywał w Niemczech jeszcze na przełomie XVI i XVII w., kiedy opatrzony został dotychczas niezidentyfikowaną tarczą herbową. W wieku XIX trafił do Wielkiej Brytanii (Il. 1).

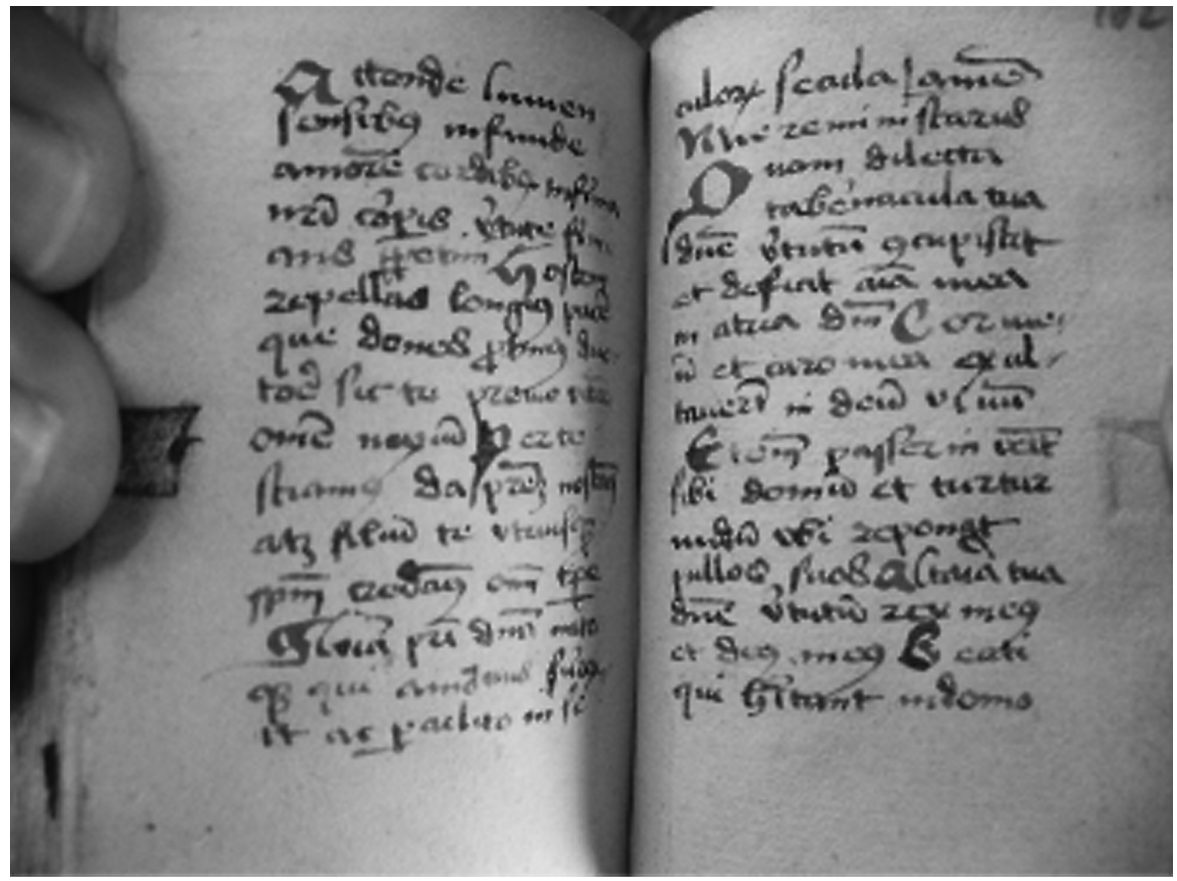

Il. 2. Dołączone modlitwy rękopiśmienne do: Officium BMV secundum usum Romanum, Wenecja: Georgius Arrivabenus i Paganinus de Paganinis, 1484, 32; GW 13364; ISTC ih00357770; własność: Oldenburg, Landesbibliothek, sygn. CIM II 209, k. 161v-162r.

Zachowane w Oldenburgu godzinki również wydrukowano w Wenecji. Jednak pochodząca $\mathrm{z}$ epoki oprawa oraz dołączone rękopiśmienne modlitwy wskazuja na pochodzenie niemieckie. Inkunabuł ten musiał trafić do Niemiec bezpośrednio po wydrukowaniu i tamże przebywa do dnia dzisiejszego, jako jedyny znany egzemplarz tego wydania (Il. 2).

Jak uchwycić te niewyraźne ślady przemieszczania się książek w czasie i przestrzeni, handel nimi i recepcję, i przetworzyć je w kategoriach chronologicznych i geograficznych? Celem jest wyłowienie dwóch wyżej 
wymienionych przykładów w trakcie przeszukiwania bazy danych pod kątem książek wydrukowanych w Wenecji i funkcjonujących w Niemczech w XV, XVI lub XVII w.; albo książek wydrukowanych w Wenecji i obecnych w Anglii w wieku XIX; albo książek użytkowanych przez zakonników w wieku XV; albo - jeszcze inaczej - poszukując odpowiedzi na pytanie: kto kupował dzieła filozoficzne w XV wieku?

Odpowiedź jest relatywnie prosta. Wystarczy oznaczyć tagami geograficznymi i chronologicznymi każdy element informacji źródłowej, bez względu na to czy dotyczy on byłego właściciela (np. notka własnościowa lub pieczątka), czy anonimowych jak np. dekoracji, oprawy, albo rękopiśmiennych uwag na marginesach - elementów dających się datować i przyporządkowywać geograficznie przez ekspertów.

Pomysł, który legł u podstaw stworzenia MEI oraz Projektu ERC, poświęconego piętnastowiecznemu handlowi książką, to posłużenie się materiałem źródłowym zawartym w tysiącach zachowanych inkunabułów celem znalezienia odpowiedzi na cztery fundamentalne pytania, odnoszące się do początków druku na Zachodzie, a dotyczące zagadnień, które jak dotąd umykały badaczom po części ze względu na brak źródeł, po części zaś z powodu braku sprawnych narzędzi badawczych, umożliwiających analizę tych danych źródłowych, którymi dysponowano. Pytanie pierwsze dotyczy rozprzestrzeniania się książek drukowanych i dróg handlowych, tak krajowych jak i międzynarodowych, którymi się rozchodziły w XV w., a także ich recepcji, tzn. tożsamości kupujących i użytkowników (osoby prywatne, instytucje religijne i świeckie, kobiety, mężczyźni, i ich zawody), oraz ich praktyk czytelniczych; drugie - ówczesnej wartości rynkowej książki; trzecie - transmisji i rozchodzenia się tekstów zawartych w drukach, ich przetrwania lub zatraty; czwarte zaś - obrotu i ponownego używania ilustracji.

W odniesieniu do problemu rozchodzenia się i użytkowania książek weneckich, autorka niniejszych słów przeprowadziła w 2008 roku sondę pilotażowa, która w konsekwencji doprowadziła do uruchomienia omawianego projektu badawczego pod auspicjami British Academy i stworzenia bazy $\mathrm{MEI}^{4}$. Owe badania pilotażowe oparte były o 1123 edycje weneckie (jedną trzecią wszystkich), reprezentowane przez 1387 egzemplarzy książek z Biblioteki Bodlejańskiej oraz ich opisy w katalogu in-

${ }^{4}$ C. Dondi, The Venetian Booktrade: A Methodological Approach to and First Results of Book-based Historical Research, in Early Printed Books as Material Objects, IFLA Pre-Conference, Munich, August 2009, ed. B. Wagner and M. Reed, Munich, Saur, 2010, s. 221-29. 
kunabułów tej biblioteki (dalej: Bod-inc) ${ }^{5}$. Na potrzeby sondy, podobnie jak obecnie w bazie MEI, zebrane zostały nie tylko expressis verbis wyrażone wpisy posesorskie, lecz także informacje pozyskane na podstawie analizy zdobnictwa, opraw, odręcznych zapisek i późniejszych wpisów proweniencyjnych. Musiałam zapoznać się z każdą informacja, wnioskować na jej podstawie, a następnie wprowadzić zdobyte dane na arkusz kalkulacyjny według przesłanek geograficznych i chronologicznych pozyskanych z materialnych źródeł dotyczących rozmieszczenia i użytkowania książek. Pochodzenie inkunabułów z kolekcji Biblioteki Bodlejańskiej to niewielki wycinek w skali ogólnoeuropejskiej. Zbiór ten powstał pod koniec wieku XVIII i w wieku XIX, jako wynik szeroko zakrojonych zakupów dokonywanych w rozproszonych kolekcjach prywatnych i instytucjonalnych, często skasowanych zgromadzeniach zakonnych Europy kontynentalnej. Dystrybucję druków weneckich w XV i XVI w., na podstawie próbki bodlejańskiej, obrazuje poniższa tabela.

\begin{tabular}{|c|c|c|}
\hline Miejsce użytkowania & Liczba egzemplarzy & Procent całości \\
\hline Wlk. Brytania & 183 & $13 \%$ \\
\hline Niemcy & 263 & $19 \%$ \\
\hline (razem) & $(446)$ & $(32 \%)$ \\
\hline & & $34 \%$ \\
\hline Włochy & 481 & $3 \%$ \\
\hline Inne kraje & 46 & $16 \%$ \\
\hline Notatki odręczne & 232 & $14 \%$ \\
\hline Brak danych & 194 & \\
\hline
\end{tabular}

183 egzemplarze (13\%) sprowadzono do Anglii, Szkocji i Walii, 263 (19\%) kopii znalazło się w Niemczech, a 481 książki (34\%) - bardzo znacząca liczba-krążła, była kupowana i przechowywana we Włoszech. Zajmując się weneckim handlem książkami nie wolno zapominać, że obrót lokalny, tzn. skierowany do innych części Włoch i samej Wenecji, był równie ważny, co międzynarodowy, ponieważ w oczach badaczy handel międzynarodowy całkowicie przysłonił obrót wewnętrzny. Ku memu zaskoczeniu, systematyczny sposób, w jaki wprowadzono dane materialne do Bod-inc umożliwił zlokalizowanie wczesnych użytkowników książek, a tym samym dystrybucję 572 książek, co do których brak informacji na temat ich posiadaczy. Stanowi to $41 \%$ wszystkich druków weneckich zachowanych w Bibliotece Bodlejańskiej. Spośród nich, w przypadku 232 tomów (16\%), kraj, do których trafiły, ustalono na podstawie mar-

\footnotetext{
${ }^{5}$ Obecnie dostępny pod adresem: http://incunables.bodleian.ox.ac.uk/.
} 
ginaliów, czyli w oparciu o dane paleograficzne. Ogólnie, udało mi się zgromadzić informacje na temat wczesnej proweniencji dla 86\% książek, tzn. dla 1205 woluminów, z całkowitej liczby 1387. Tylko w przypadku 194 egzemplarzy (14\%) jakakolwiek lokalizacja geograficzna okazała się niemożliwa.

Inkunabuły przechowywane w Bibliotece Bodlejańskiej nie są wyjątkowe pod względem zachowanych na ich oprawach i kartach danych historycznych, co do ich użytkowania (tylko w wyjątkowych wypadkach książka licząca 500 lat lub więcej nie nosi śladów po jej posiadaczach). Wyjątkowy jest natomiast katalog inknabułów tej biblioteki, z uwagi na systematyczne zarejestrowanie szczegółowych danych. Niemniej, przegląd pozycji katalogowych to tylko początek badań. W następnej kolejności dane pozyskane z katalogu musiałam przenieść na tabele komputerowe, porządkując je pod względem geograficznym i chronologicznym, by owe tabele wydobyły zawartość historyczną książek i wpisów katalogowych. Zadanie to było bardzo czasochłonne i nie dziwi mnie, że podobne procedury nie są podejmowane zbyt często.

Czynności te unaoczniły mi konieczność opracowania systemu, który umożliwiałby sprawne przetwarzanie posiadanych informacji, systemu, który byłby zdolny do zapisywania i przetwarzania owych ,,anonimowych wskaźników" (takich jak: oprawa, styl zdobnictwa, lokalizowanie poszczególnych rąk wśród marginaliów itp.), nieocenionych z punktu widzenia odtwarzania dziejów krążenia książki i handlu nią.

Przeszło dziesięć lat spędzonych przy pracy nad inkunabułami w Bibliotece Bodlejańskiej, i kilka w innych bibliotekach, nauczyły mnie, że danych źródłowych jest dużo, jednakże jest niesłychanie ważne, by dane te były nie tylko zbierane $\mathrm{z}$ pietyzmem - mam tu na myśli solidne katalogowanie konwencjonalne (bez względu na to czy na papierze czy w komputerowych bazach danych) - lecz także inteligentnie pozyskiwane z tychże katalogów.

W MEI omawiany wyżej egzemplarz Arystotelesa wygląda następująco:

Właściciele książek są następnie określani według płci, stanu (duchowny lub świecki), zawodu (lekarz, prawnik, polityk, duchowny, nauczyciel, przedsiębiorca, scholar, wykładowca uniwersytecki, student, urzędnik, księgarz, bibliotekarz itp.) oraz instytucji (uniwersytet, firma, akademia, księgarnia, urząd miejski, biblioteka). Doprecyzowana zostaje jego rola: autor marginaliów, księgarz, donator, były właściciel, obecny właściciel, bibliotekarz, notariusz. Zdefiniowany zostaje także sposób pozyskania książki: kupno, dar, legat, zamiana, transfer instytucjonalny (czyli efekt 
Piętnastowieczny handel książką. Gromadzenie świadectw źródłowych...
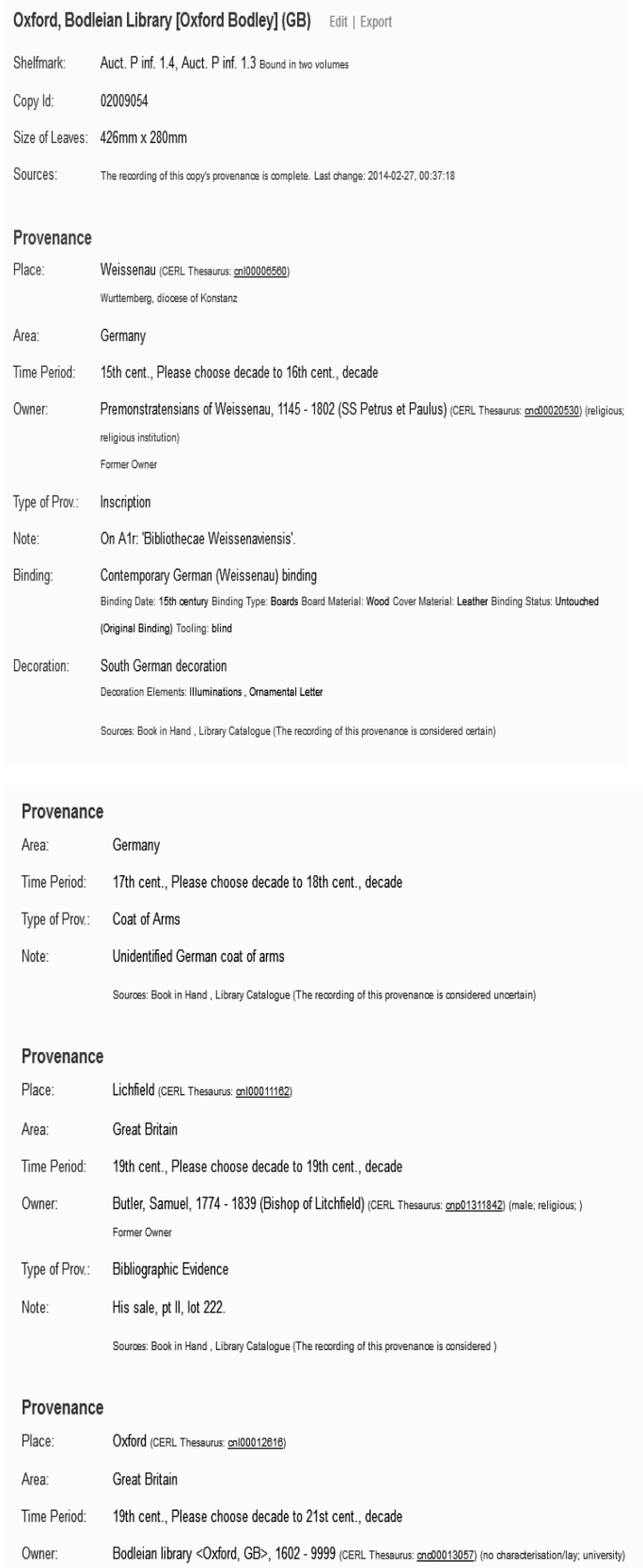

Il. 3. Rekord omawianego wydania dzieł Arystotelesa w bazie MEI sekularyzacji). Specjalne miejsce przeznaczone jest na odnotowanie typu źródeł, na podstawie których dokonywana jest datacja i umiejscowienie książki: herb, tablice genealogiczne, superekslibris, ekslibris, motto, emblemat, pieczątka, ślepe tłoczenie, oprawa, zdobienia, notki rękopiśmienne, źródła bibliograficzne, sygnatura. $\mathrm{W}$ ten sposób łatwo ustalić, którzy z dawnych właścicieli zostali ustaleni w oparciu o oprawy, notatki, czy też inne spośród wymienionych kategorii.

Elementy zdobnictwa książki są umieszczane pod następującymi kategoriami: ilustracje kolorowane ręcznie, iluminacje, ozdobne litery, inicjały piórkiem, herby, rubrykacja, ilustracje odbite. Noty rubrykatorskie i ich datacja są zapisywane indywidualnie.

Marginalia są kwalifikowane według kryteriów kwantytatywnych (przypadkowe, pojedyncze, kilkakrotne, całościowe, ekstensywne) i jakościowych: poprawki, dopełnienia, dodatki, hasła wywoławcze, kolacjonowanie, przekłady, strukturyzowanie tekstu, komentarze, cenzurowanie, znaki czytelnicze (tzn. pod- 
kreślenia i „rączki”), rysunki, poprawki/notatki ilustratora, notatki z wykładów.

Na koniec odnotowywane są także sygnatury historyczne ${ }^{6}$ i ceny, które traktowane są oddzielnie.

Naturalną koleją rzeczy, każda z kategorii wymienionych powyżej może być indywidualnie przeszukiwana, jak również $\mathrm{w}$ powiązaniu $\mathrm{z}$ innymi, oraz $\mathrm{w}$ połączeniu $\mathrm{z}$ danymi bibliograficznycmi z ISTC: $\mathrm{np}$. wszystkie książki z rubrykacja, wszystkie książki z notatkami cenzorskimi, wszystkie książki z szesnastowiecznymi oprawami, itd.

MEI umożliwia inteligentne, zakrojone na szeroką skalę przeszukiwanie fizycznych danych ponieważ tradycyjne katalogowanie jest zmodyfikowane na trzy sposoby:

1. dane fizyczne są skonwertowane na historyczne i poddane kwantyfikacji;

2. uchwycone jest krążenie książek w postaci danych o handlu nimi i użytkowaniu ich;

3. zintegrowane są $\mathrm{w}$ jedno przeszukiwalne środowisko zachowane dane pochodzące $\mathrm{z}$ różnych źródeł: katalogów papierowych, książek właśnie nabytych, a wkrótce także $\mathrm{z}$ baz elektronicznych, dzięki czemu umożliwione jest badanie ponad granicami instytucjonalnymi i państwowymi.

Według statystyk aktualnych na koniec października 2013 r., dostępne były dane rodem z ok. 3633 wydań, reprezentowanych przez 6575 książek; danych w większości uzyskanych w oparciu o autopsję konkretnych egzemplarzy. Można o tym przeczytać na portalu MEI ${ }^{7}$.

Oczywiście, wszystkie dane wprowadzane do MEI są automatycznie przekazywane jednocześnie do Tezaurusa CERL (CT). W ten sposób MEI także służy rekonstruowaniu kolekcji rozproszonych, co jest jednym z głównych celów bazy CT.

\section{Historia MEI}

MEI jest udanym przykładem współpracy w sieci bibliotek europejskich i północno-amerykańskich. Przeszło czterdzieści osób uczestniczy w tym projekcie; wiele $\mathrm{z}$ nich to znakomicie przygotowani młodzi badacze, którzy jednak nie dopracowali się jeszcze stałych miejsc pracy. MEI daje im możliwość bliskiego współdziałania razem z doświad-

${ }^{6}$ Stopniowo budowana jest tablica wzorów sygnatur historycznych, by można było identyfikować anonimowe dawne sygnatury (por. http://www.cerl.org/help/incunabula/ shelfmark_patterns).

${ }^{7}$ Por. http://www.cerl.org/resources/mei/main. 
czonymi uczonymi i bibliotekarzami. Możliwość takiej współpracy jest przez nich bardzo wysoko oceniana. Wprowadzanie rekordów jest nieodpłatne i mile widziane. Obecnie dysponujemy dwoma interfejsami - angielskojęzycznym i włoskim, ale w niedługim czasie uruchomiona zostanie wersja niemiecka. Zalogowawszy się do MEI można wprowadzać rekordy w formatach MARC21 lub UNIMARC Holdings, które zapewniają integrację z lokalnymi katalogami online. Bazę MEI stworzyłam osobiście, a następnie została ona udoskonalona przez Alexadra Jahnke z Data Conversion Group Uniwersytetu w Göttingen. Projekt sfinansowała British Academy przyznajacc odpowiednie fundusze w ramach grantu British Academy Research Development Award (dalej: BARDA), który otrzymałam razem z profesorem Nigelem Palmerem w 2009 r. Baza posadowiona jest i utrzymywana na serwerze CERL. Korzystanie z niej jest bezpłatne, a dostęp możliwy jest przez portal CERL. Później, kolejne grupy współpracujące przy projekcie - przede wszystkim zespół profesora Edoardo Barbieriego z Centro di Ricerca Europeo Libro Editoria Biblioteca (= CRELEB) na Università Cattolica w Mediolanie - otrzymywały granty od samorządów regionalnych (np. Regione Lombardia), fundacji (np. Fondazione Cariplo) oraz od włoskiego Ministerstwa Nauki (grant PRIN).

W grudniu 2013 r. otrzymałam pięcioletni Consolidator Grant od Europejskiej Rady ds. Badań Naukowych ${ }^{8}$ na projekt zatytułowany „Piętnystowieczny handel książką: Ocena i wizualizacja oparta na źródłach historycznych dystrybucji, sprzedaży i recepcji książek w dobie Odrodzenia". Grant ten pozwoli na poważne rozwinięcie i ulepszenie bazy MEI, poprawienie bazy Incunabula Short Title Catalogue (ISTC), zbadanie dziennika piętnastowiecznego księgarza weneckiego, w którym odnotowana została sprzedaż 25,000 druków wraz z ich cenami (wspólnie $z$ profesorem Neilem Harrisem), skatalogowanie na podstawie autopsji kolekcji inkunabułów Rosyjskiej Biblioteki Narodowej w Petersburgu, stworzenie nowej bazy danych w celu zbadania korpusu tekstów wydrukowanych w XV w. (według wzorca Bod-inc), eksperymenty z zastosowaniem oprogramowania do rozpoznawania obrazów do piętnastowiecznych ilustracji książkowych oraz z naukową wizualizacją danych MEI w zakresie dystrybucji i użytku książki. Przewiduje się ogłoszenie kon-

${ }^{8}$ Europejska Rada ds. Badań Naukowych (European Research Council) to ciało przyznające fundusze, których zadaniem jest wspieranie wysiłków naukowych najlepszych badaczy i inżynierów w UE. Jej celem jest dbanie o najwyższy poziom badań, wybranych w drodze recenzowania przez specjalistów. Instrumentem rady jest wysoki poziom finansowania, obliczony na wspieranie projektów reprezentujących najbardziej zaawansowane badania reprezentujące różne dyscypliny naukowe. 
kursu na trzech pracowników ze stopniem doktora i jeden dla doktora ze stopniem oksfordzkim (DPhil) w pierwszej połowie $2014 \mathrm{r}$.

\section{Jeden przykład za wszystkie}

Niedawno poproszono mnie we Florencji, bym omówiła nowy katalog inkunabułów, opracowany dla tamtejszej zbiorów Prowincji Franciszkańskiej'.

W ostatnich latach wspomniana biblioteka florencka zgromadziła pod swym dachem szereg kolekcji klasztorów franciszkańskich z całej Toskanii. Przeglądając ważny rozdział, poświęcony znakom proweniencyjnym, omawiający dzieje każdej z kolekcji, ilustrowany podobiznami ich wpisów własnościowych, pieczęci i dawnych sygnatur, zwróciłam uwagę na znaną mi nazwę „Libraria di S. Cerbone”. Indeks proweniencji katalogu inkunabułów Biblioteki Bodlejańskiej (Bod-inc) rejestruje bliżej nieokreślona Libraria di S. Cerbone z XVI wieku. Informacja ta widnieje pod wpisem: „Franciscus de Platea, Opus restitutionum, usurarum, excommunicationum, Venice: Johannes de Colonia and Johannes Manthen, 22 Jan. 1477. Folio (ISTC ip00758000; MEI 02005171; Bodley Auct. 2Q inf. 2.15; Bod-inc P-337)". Kiedy pracowaliśmy nad Bod-inc, nie udało się odszukać bliższych informacji na temat lokalizacji tej biblioteki. Teraz już wiem, że książka ta należała do franciszkanów z klasztoru San Cerbone w Lukce - biblioteki, która została przeniesiona w XX wieku do prowincjalnej książnicy we Florencji. Wszelako, jeżeli jeden inkunabuł trafił do Bodleian Library, inne również muszą być rozsiane po świecie. Tylko gdzie ich szukać? Najpierw zajrzałam do Index Possessorum Incunabulorum (IPI) autorstwa Paula Needhama, teraz dostępnego już na stronie CERL (http://ipi.cerl.org/). Natychmiast trafiłam na odsyłacz do biblioteki w Yale i sygnatury N-273, czyli Nonius Marcellus, De proprietate latini sermonis, etc. Venetia: Antonius de Gusago, 12 II 1498, folio (ISTC in00273000; MEI 02005170; Yale 1977+187). Dzięki uprzejmości Elizabeth Frengel odnalazłam materiały zebrane dla potrzeb IPI. Okazało się, że w książce z Yale notka proweniencyjna „S. Cerbone” wpisana jest wzdłuż przedniej krawędzi bloku tomu, tak jak na fotografii w katalogu florenckim. W drugiej kolejności zajrzałam do MEI (http://incunabula. cerl.org). Poszukiwania sygli „S. C.” - czyli jednego ze sposobu opatrywania znakiem własnościowym, stosowanym przez rzeczoną bibliotekę naprowadziły mnie na egzemplarz przechowywany w Houghton Library

${ }^{9}$ Gli incunaboli della Biblioteca Provinciale dei Frati Minori di Firenze, ed. Chiara Razzolini, Elisa di Renzo, Irene Zanella, with an essay of Neil Harris, Florence, Regione Toscana, Pacini Editore, 2012. 
w Harvard. Jest to Paulus de Sancta Maria, Scrutinium scripturarum, Mainz: Peter Schoeffer, 7 I 1478, folio (ISTC ip00205000; MEI 02005016; Houghton WKR 21.6.3; Walsh 19).

John Lancaster wprowadza do MEI dane dotyczące inkunabułów przechowywanych w Houghton Library, pierwotnie opublikowane w katalogu Walsha ${ }^{10}$. Dzięki rzetelnemu opisowi książki, nawet jeżeli nie doprowadził on natychmiast do zidentyfikowania zabytku, mogłam skupić się na niezrozumiałym napisie na brzegu bloku tomu. Natychmiast poprosiłam Williama Stonemana o zdjęcia (uprzejmie wykonane przez Monique Duhaime), aby je porównać z materiałem z katalogu florenckiego. Przesyłając je, Stoneman załączył znamienny komentarz: „Czy nie byłoby wspaniale, gdyby się okazało, że faktycznie chodzi o San Cerbone, jeśli nie moga to być inicjały Sydneya Cockerella ${ }^{11}$ ?" Porównanie, oczywiście, potwierdziło podejrzenie, że egzemplarz zachowany w Yale pochodzi z San Cerbone w Lukce.

Egzemplarz z Houghton Library został zakupiony przez Adolphusa Willamsona Greena (1843-1917) z Nowego Jorku. Odziedziczyła go po nim jego córka, żona Normana P. Reama, która w czerwcu 1951 r. podarowała go Bibliotece Harvard College.

Egzemplarz z Yale zakupiono we wrześniu 1987 r. Niemniej inkunabuł z Biblioteki Bodlejańskiej wskazuje drogę, jaką mogły one w początkach XIX w. opuścić klasztor San Cerbone i trafić na rynek antykwaryczny. Zapewne, w wyniku zaburzeń spowodowanych przez sekularyzacyjne posunięcia wielkiego księcia Toskanii Piotra Leopolda (pan. 1765-1790) i Napoleona (w latach 1808-1810), książka ta stała się własnością kolekcjonerów z Lukki: Giacomo (1753-1820) i Cesare (1756-1832) Lucchesinich. W 1834 r. zasadnicza część zbiorów Lucchesinich została nabyta przez rząd w Lukce i włączona do miejskiej biblioteki publicznej. Niemniej, część książek z tej kolekcji musiała zostać sprzedana wcześniej, na co dowodem jest egzemplarz z Biblioteki Bodlejańskiej. W 1832 r. zakupił go we Florencji w bliżej nieznanych okolicznościach, wraz z 16 innymi książkami ze zbiorów Lucchesinich, za kwotę czterech funtów i sześciu pensów oksfordzki księgarz David Alphonso Talboys dla Bodleiany. Wydaje się bardzo prawdopodobne, że wyżej omówione książki, rodem z San Cebrone, obecnie przechowywane w Stanach Zjednoczonych również zakupiono we Florencji w 1832 r.

${ }^{10}$ James Walsh, A Catalogue of the Fifteenth-Century Printed Books in the Harvard University Library, 5 vols, Binghamton, N.Y. 1991-1997 (Medieval \& Renaissance Texts and Studies, 84, 97, 119, 150,171).

${ }^{11}$ Sir Sydney Carlyle Cockerell (1867-1962) był angielskim badaczem i dyrektorem Fitzwilliam Museum w Cambridge od 1908 do 1937. 
Dzięki MEI inkunabuły z San Cerbone - po jednym w Oksfordzie, Yale i na Harvardzie, oraz 39 we Florencji - zostały ponownie połączone w jedna kolekcję. A Chiara Razzolini, obecnie pracująca nad MEI, opisze w bazie wszystkie inkunabuły z florenckiej Biblioteca Provinciale dei Frati Minori.

Nadszedł wreszcie czas, kiedy tego rodzaju odkrycia nie będa już łutem szczęścia lub efektem długich godzin spędzonych nad różnego rodzaju pomocami bibliotecznymi. Umożliwiają to: wieloletnie wysiłki szczegółowego katalogowania inkunabułów, pojawienie się narzędzia, które pozwala zebrać w jednym miejscu wszystkie te cenne dane, upowszechnienie wśród bibliotekarzy świadomości, że integrowanie danych jest ważne i potrzebne, oraz fundamentalna praca osób tworzących $\mathrm{MEI}^{12}$.

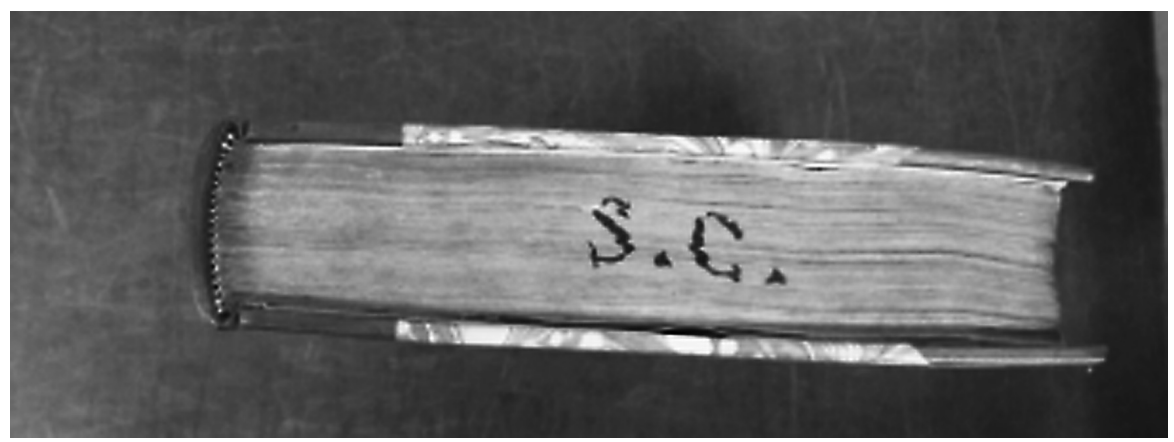

Il. 4. Sygla „S.C.” umieszczone na brzegu bloku książki: Paulus de Sancta Maria, Scrutinium scripturarum, Mainz: Peter Schoeffer, 7.01.1478, folio (Houghton Library, Harvard University).

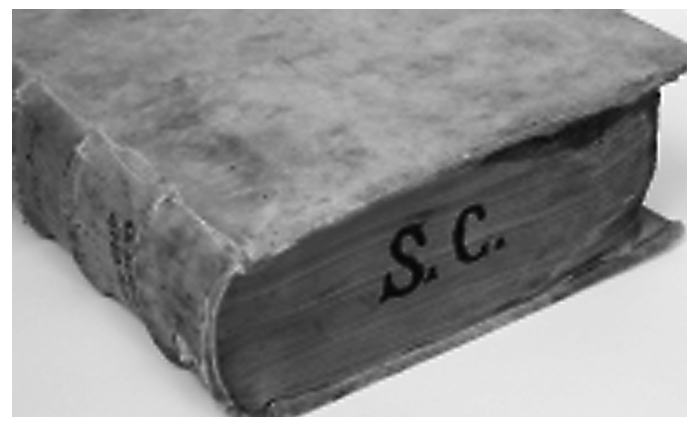

Il. 5. Sygla „S.C.” na górnej krawędzi bloku książki Guilhelmus Ocham, Quaestiones et decisiones in quattuor libros Sententiarum Petri Lombardi. Centilogium theologicum, Lugduni: Johannes Trechsel, 9-10 XI 1495, ISTC io00015000, własność: Florencja, Biblioteca Provinciale dei Frati Minori, BPF INC.2.3.

${ }^{12}$ Przypadek ten omówiłam w blogu Houghton Library, zapowiedziana przez Williama Stonemana, kuratora działu dawnych książek i rękopisów tejże biblioteki na Uniwersytecie Harvarda. Tytuł tego blogu - Contributing Data for Greater Understanding (Przekazywanie danych w celu pogłębienia rozumienia) jest bardzo wymowny. Wpis ten ukazał się po wykładzie i seminarium, które miałam w Houghton Library 7 i 10 października 2013 r. (http://blogs.law.harvard.edu/houghton/2013/10/11/contributing-datafor-greater-understanding/). 
Piętnastowieczny handel książką. Gromadzenie świadectw źródłowych...

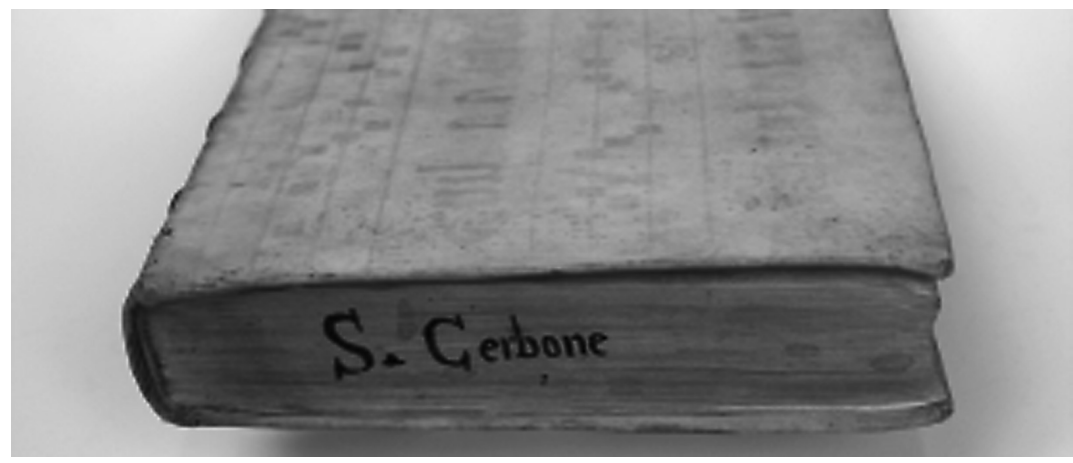

Il. 6. Notka własnościowa „S. Cerbone” na dolnej krawędzi bloku książki Guilhelmus Ocham, Quaestiones...

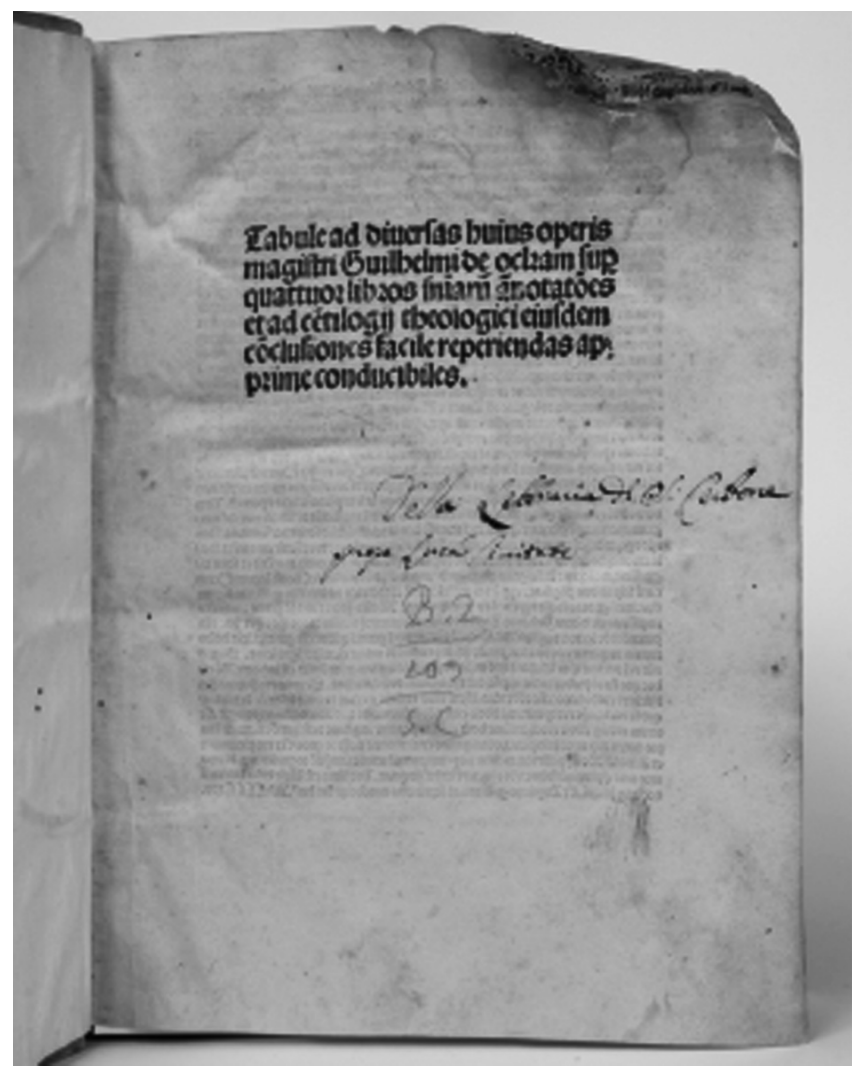

Il. 7. Notką własnościowa „Della Libraria di San Cerbone prope Lucam civitatem" na karcie książki Guilhelmus Ocham, Quaestiones... 
W podsumowaniu trzeba podkreślić, że w zakresie badań nad wczesną książką drukowaną nastały wielce ciekawe czasy. Współpraca naukowców, bibliotekarzy i informatyków - najsilniejsza strona CERL - przynosi niesamowite wyniki, które w ostatecznym rozrachunku kładą podwaliny pod nowe, bardzo ciekawe badania. W efekcie powstaną nowoczesne monografie, oparte na bardzo szerokiej bazie źródłowej, ukazujące wpływ druku na rozwój społeczny, ekonomiczny, intelektualny i naukowy Europy i kontynentów amerykańskich. Monografie te zaś, dzięki ich podstawie źródłowej, staną się zaczynem nowych dyskusji wśród historyków.

tłum. Jacek Soszyński

\section{Streszczenie}

\section{Piętnastowieczny handel książka. Gromadzenie świadectw źródłowych i badanie inkunabułów - baza danych MEI}

Wynalazek druku wywarł wielki wpływ na społeczeństwa wczesnonowożytnej Europy. Do dnia dzisiejszego zachowało się ok. 1,2 mln inkunabułów, reprezentujących w przybliżeniu 30 tys. wydań. Zabytki te przechowywane są w czterech tysiącach bibliotek, przede wszystkim europejskich i północnoamerykańskich. Stan opracowania inkunabułów w różnych krajach systematycznie wzrasta. Niemniej powstające katalogi i bazy danych sa rozproszone, co powoduje, że badacze muszą wyszukiwać dane w różnych pomocach, w których metoda i szczegółowość opracowania jest nierówna. Sytuacja ta w poważnym stopniu utrudnia, a w niektórych przypadkach uniemożliwia, przekrojowe badania. By zaradzić tym bolączkom został uruchomiony projekt MEI, czyli jednolitej bazy danych, która docelowo zespoli szczegółowe informacje proweniencyjne na temat wszystkich zachowanych egzemplarzy inkunabułów na całym świecie. Baza ta, dzięki swemu zasięgowi geograficznemu, zezwoli także na odtwarzanie idealne księgozbiorów, które na skutek różnych kolei losu zostały rozproszone, niekiedy dosłownie po całym świecie. Autorka ilustruje to przykładem odkrytych przez siebie inkunabułów, które do końca XVIII w. należały do klasztoru San Cerbone w Lukce, a obecnie znajdują się w bibliotekach w Oksfordzie, Yale i Harvard. Dzięki danym MEI informacje o tych książkach te można było połączyć z opisami podstawowego zrębu księgozbioru San Cerbone, który obecnie przechowywany jest w Bibliotece Prowincjalnej Braci Mniejszych we Florencji. 


\section{Summary}

\section{Fifteenth-Century Booktrade: Collecting and Researching the Material Evidence of Incunabula: The MEI Database}

The significance of the printed book for the development of early modern Europe can hardly be overestimated. Some 30,000 editions of incunabula survive today, in some 450,000 surviving copies, located in about 4,000 different public libraries, mostly in Europe and North America. During the last century, cataloguing of incunabula in libraries all around the world has progressed notably, but the printed and on-line inventories available describe the books in various degrees of detail and, what is more disappointing, remain separate entities, which renders any kind of all-encompassing survey exceedingly lengthy, if not impossible. To overcome such hindrances the Material Evidence in Incunabula (MEI) database has been set up. It integrates existing provenance records as well as providing a space for cataloguing incunabula, which have not been catalogued yet. The database, although far from completion, already enables to start reconstructing dispersed book collections. Cristina Dondi illustrated this with the example of three incunabula she found in libraries in Oxford, Yale, and Harvard, which until the early 19th century belonged to the library of the Franciscan convent of San Cerbone in Lucca. Thanks to the data provided by MEI, it is now possible to connect the descriptions of these three incunabula with the main part of the San Cerbone collection, now kept at the Provincial Library of the Franciscans in Florence. 